\title{
Mycobacterium leprae in six-banded (Euphractus sexcinctus) and nine-banded armadillos (Dasypus novemcinctus) in Northeast Brazil
}

\author{
Cristiane Cunha Frota ${ }^{1}{ }^{+}$, Luana Nepomuceno Costa Lima ${ }^{1}$, Adalgiza da Silva Rocha ${ }^{2}$, \\ Philip Noel Suffys ${ }^{2}$, Benedito Neilson Rolim³ ${ }^{3}$ Laura Cunha Rodrigues ${ }^{4}$, \\ Maurício Lima Barreto ${ }^{5}$, Carl Kendall ${ }^{6}$, Ligia Regina Sansigolo Kerr ${ }^{7}$
}

\author{
${ }^{1}$ Departamento de Patologia e Medicina Legal ${ }^{7}$ Departamento de Saúde Comunitária, Faculdade de Medicina, \\ Universidade Federal do Ceará, Fortaleza, CE, Brasil '2Laboratório de Biologia Molecular Aplicada a Micobactérias, \\ Instituto Oswaldo Cruz-Fiocruz, Rio de Janeiro, RJ, Brasil ${ }^{3}$ Controle de Zoonoses/Vetores, Secretaria de Saúde do Estado do Ceará, \\ Fortaleza, CE, Brasil ${ }^{4}$ London School of Hygiene and Tropical Medicine, London, UK ${ }^{5}$ Instituto de Saúde Coletiva, \\ Universidade Federal da Bahia, Salvador, BA, Brasil ${ }^{6}$ Department of Global Community Health and Behavioral Sciences, \\ Center for Global Health Equity, Tulane University School of Public Health and Tropical Medicine, New Orleans, LA, USA
}

Human beings are the main reservoir of the causative agent of leprosy, Mycobacterium leprae. In the Americas, nine-banded armadillos (Dasypus novemcinctus) also act as a reservoir for the bacillus. In the state of Ceará (CE), which is located in Northeast Brazil and is an endemic area of leprosy, there are several species of armadillos, including D. novemcinctus and Euphractus sexcinctus (six-banded armadillo). Contact between humans and armadillos occur mainly through hunting, cleaning, preparing, cooking and eating. This study identified M. leprae DNA in the two main species of armadillos found in Northeast Brazil. A total of 29 wild armadillos (27 D. novemcinctus and $2 \mathrm{E}$. sexcinctus) were captured in different environments of CE countryside. Samples from the ear, nose, liver and spleen from each of these animals were tested by a nested $\mathrm{M}$. leprae-specific repetitive element polymerase chain reaction assay. The samples that tested positive were confirmed by DNA sequencing. M. leprae was detected in $21 \%$ (6/29) of the animals, including five D. novemcinctus and one E. sexcinctus. This is the first Brazilian study to identify the presence of a biomarker of $\mathrm{M}$. leprae in wild armadillos (D. novemcinctus and $\mathrm{E}$. sexcinctus) in a leprosy hyperendemic area where there is continuous contact between humans and armadillos.

Key words: Euphractus sexcinctus - Dasypus novemcinctus - Mycobacterium leprae - eco-epidemiology - leprosy

Mycobacterium leprae, the causative agent of leprosy, is not cultivable in vitro. The lack of growth on standard mycobacterial isolation media differentiates this organism from other mycobacterial pathogens. Human beings are the only known reservoir of infection, except in the southern United States of America (USA), where ninebanded armadillos (Dasypus novemcinctus) are believed to also provide a reservoir (Truman et al. 2011).

In 1960, Shepard introduced the footpad mouse model to study experimental leprosy. In 1971, nine-banded armadillos were successfully infected with the bacillus and developed clinical symptoms and pathologies similar to the human disease (Kirchheimer et al. 1972, Kirchheimer \& Sanchez 1977). Armadillos provide a much more effective animal model than the mouse footpad, producing $10^{6}$ acid-fast bacilli/mL (Shepard 1985). Because armadillos do not breed well in captivity, the animals to be used in the laboratory need to be captured in the wild. While searching for these animals in 1975, Walsh et al. (1977) found armadillos that were naturally infected with

Financial support: CNPq (308539/2006-0), FUNCAP (303/05), CAPES (PROCAD 0204056)

+ Corresponding author: cristianefrota71@gmail.com

Received 3 April 2012

Accepted 11 July 2012
M. leprae in the wild for the first time. The authors proposed that armadillos might have acquired leprosy infections from untreated human patients in the USA.

The exact mode of transmission of leprosy between humans and armadillos is not known, though cross-reactivity between IgM antibodies against phenolic glycolipid-I of humans and armadillos has been reported (Truman et al. 1991, Job et al. 1992). Infected nine-banded armadillos have been identified in the states of Texas and Louisiana and in Central and South America (Smith et al. 1983, Amezcua et al. 1984, Stallknecht et al. 1987, Zumarraga et al. 2001). Additionally, biomarkers of armadillo infection have been detected in Colombia and Brazil (Deps et al. 2007, Cardona-Castro et al. 2009). Several studies have shown an association between armadillo exposure through hunting, cleaning and eating the meat and the development of leprosy (Clark et al. 2008, Deps et al. 2008, Truman 2008). More than half of the leprosy cases that have been reported in the southeastern USA have described some direct or indirect exposure to armadillos (Bruce et al. 2000, Truman et al. 2011) and other studies have raised the hypothesis that exposure to these animals could be a significant risk factor for leprosy in Brazil (Kerr-Pontes et al. 2006, Deps et al. 2008).

Unlike Brazil, where there are other species of armadillos, only D. novemcinctus is found in the USA. Among the 21 species of armadillos found in Brazil, Euphractus sexcinctus (six-banded armadillo) is commonly found. This species is known to eat animal carcasses, justifying 
the local name of "vulture or gravedigger" and, because of this, hunters keep the animal alive and caged for several days before eating (Dalponte \& Tavares-Filho 2004, Armadillo Online! 2012). This type of "quarantine" is believed to "clean" the animal, but instead enhances its contact with humans. In the state of Ceará (CE), located in Northeast Brazil, armadillos are used as a source of meat and hunting is seen as a leisure pursuit.

Brazil is a high leprosy-burdened country, with 34,894 new cases detected in 2010 (WHO 2011). More than half $(53.5 \%)$ of the cases are concentrated in areas where only $17.5 \%$ of the population live, which reflects that leprosy is a rural disease (MS/SVS 2008). A study conducted with cases reported to the Brazilian Ministry of Health between 1990-2007 shows that leprosy is geographically concentrated, and a spatial analysis shows 29 clusters of higher prevalence. In these clusters, the mean rate of detection was more than the double the rate of the rest of the country (56.2 vs. 20.6 cases per 100,000 inhabitants). CE is one of the poorest states in Brazil and more than half of the municipalities in CE (46 out of 84) reported local transmission of new cases. CE was also included in one of the 29 Brazilian leprosy clusters (Penna et al. 2009). However, in Brazil, epidemiological studies are still controversial in terms of whether armadillo meat intake and direct animal contact are associated with leprosy infection (Kerr-Pontes et al. 2006, Deps et al. 2008, Schmitt et al. 2010). Aiming to investigate the question further, we used molecular diagnostic tools to search for M. leprae DNA in the two main species of wild armadillos found in CE (D. novemcinctus and E. sexcinctus).

\section{MATERIALS AND METHODS}

Armadillos - A total of 29 wild armadillos from two species ( 27 D. novemcinctus and 2 E. sexcinctus), consisting of males and females weighing from 2.6-3.8 kg, were captured between July-August 2007. The animals were captured by local hunters under the supervision of a veterinarian in rural sites of 12 selected endemic municipalities from CE (Figure). Biopsy samples from the ear, nose, liver and spleen of each of these animals were studied.

Euthanasia - Animal captures were authorised by the Brazilian Institute of Environmental and Renewable Natural Resources. Before euthanasia, armadillos were anesthetised with tiletamine and zolazepam $(5.0 \mathrm{mg} / \mathrm{kg} / \mathrm{I} . \mathrm{M})$ (Virbac, Brazil). Euthanasia was conducted in the place of capture and the animals were kept in ice until they arrived at the laboratory in Fortaleza, the capital city of CE.

Sample biopsies and DNA extraction - Stringent precautions were necessary to avoid cross-contamination. Clean protective clothing was worn and gloves were changed frequently. Before the tissue dissection, the animals were carefully rinsed with distilled water. For each desired tissue, a sterile blade was used to cut. Ear, nose, liver and spleen samples were kept frozen at $-20^{\circ} \mathrm{C}$ in separate sterile plastic storage bags until DNA extraction was performed. The sampling extraction was conducted batch-wise, four samples at a time. The frozen sections were incubated with $50 \mu \mathrm{L}$ of $100 \mathrm{mM}$ Tris- $\mathrm{HCl}, \mathrm{pH} 8.5$, containing Tween- 20 and $60 \mu \mathrm{g}$ of proteinase $\mathrm{K}$ per mL for $18 \mathrm{~h}$ at $60^{\circ} \mathrm{C}$. The digestion was conducted at $97^{\circ} \mathrm{C}$ for $15 \mathrm{~min}$ (de Wit et al. 1991). The extract was purified once with phenol/chloroform/isoamyl alcohol (25:24:1) and then precipitated with ethanol.

Polymerase chain reaction (PCR) and nucleotide sequencing - The M. leprae-specific repetitive element (RLEP) PCR was amplified in a nested PCR reaction. The primers for RLEP2-1 (5'-ATATCGATGCAGGCGTGAG-3') and RLEP2-2 (5'-GGATCATCGATGCACTGTTC-3') amplified a 282-bp sequence of the RLEP element. The second set of inner primers, RLEP2-3 (5'GGGTAGGGGCGTTTTAGTGT-3') and RLEP2-2, amplified a 238-bp product. A $1 \mu \mathrm{L}$ aliquot of the isolated DNA was added to $24 \mu \mathrm{L}$ of PCR mix, which contained $15 \mathrm{mM}$ Tris- $\mathrm{HCl}$ ( $\mathrm{pH} 8.0$ ), $50 \mathrm{mM} \mathrm{KCl}, 1.5 \mathrm{mM} \mathrm{MgCl}$, $0.2 \mathrm{mM}$ dNTP, $5 \%$ DMSO, 1.25 units of Taq DNA Polymerase and $0.2 \mu \mathrm{M}$ of each primer. The mixture was denatured at $94^{\circ} \mathrm{C}$ for $4 \mathrm{~min}$, followed by $35 \mathrm{PCR}$ cycles $\left(30 \mathrm{~s}\right.$ at $94^{\circ} \mathrm{C}, 30 \mathrm{~s}$ at $59.6^{\circ} \mathrm{C}$ and $1 \mathrm{~min}$ at $72^{\circ} \mathrm{C}$ ), with a final extension at $72^{\circ} \mathrm{C}$ for $10 \mathrm{~min}$. Each run included negative and positive controls. For the nested PCR, $0.5 \mu \mathrm{L}$ of product was used as the DNA template. The amplification reactions were visualised on a $1.5 \%$ agarose gel. Each PCR sample was double-blind tested by different researchers in Fortaleza and Rio de Janeiro. When the results for the same sample were different, a third PCR was performed for confirmation. Different amounts of purified DNA from M. leprae (kindly donated by Dr R Truman, Louisiana State University, USA) were added to all negative PCR samples to assess the presence of inhibitory substances. A standard curve was constructed by serial dilution of purified $M$. leprae DNA ranging from $10 \mathrm{fg}-1 \mu \mathrm{g}$. Purified $M$. leprae DNA was also used as a positive control for the amplifications.

The $M$. leprae gyrA region was amplified using primers gyrAF (5'-CCCGGACCGTAGCCACGCTAAGTC-3') and gyrAR (5'-CATCGCTGCCGGTGGGTCATTA-3'). The thermal profile involved an initial denaturation at $94^{\circ} \mathrm{C}$ for $5 \mathrm{~min}$ and six cycles of $94^{\circ} \mathrm{C}$ for $45 \mathrm{~s}, 68$ to $63^{\circ} \mathrm{C}$

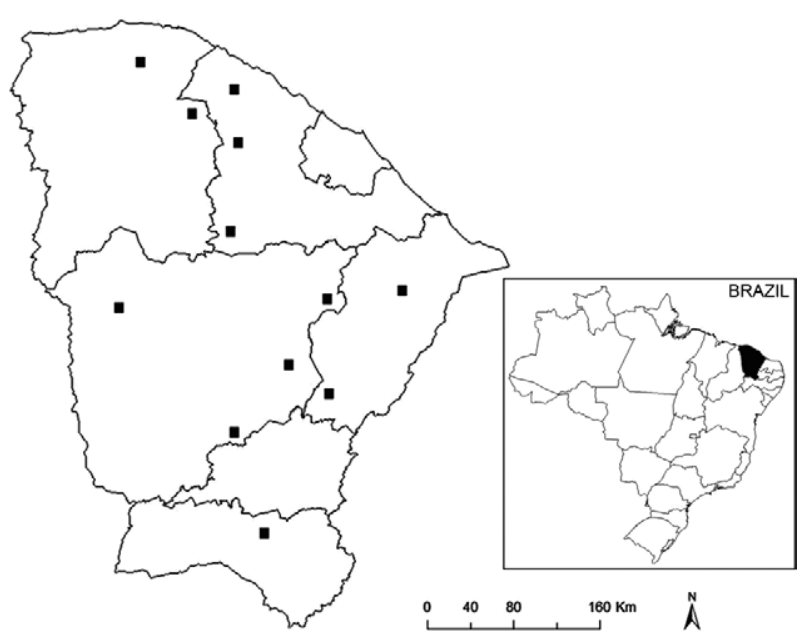

Distribution map of the 12 places where armadillos were collected in the state of Ceará, Brazil. 
for $45 \mathrm{~s}$ and $72^{\circ} \mathrm{C}$ for $90 \mathrm{~s}$, followed by 35 cycles of $94^{\circ} \mathrm{C}$ for $45 \mathrm{~s}, 62^{\circ} \mathrm{C}$ for $45 \mathrm{~s}$ and $72^{\circ} \mathrm{C}$ for $90 \mathrm{~s}$. The final extension was for $10 \mathrm{~min}$ at $72^{\circ} \mathrm{C}$. The $187-b p$ PCR products were purified using the Invitrogen ChargeSwitch PCR CleanUp kit prior to sequencing in an Applied Biosystems DNA sequencer (Perkin-Elmer Applied Biosystems) using a BigDye Terminator Cycle Sequencing kit. The sequences were identified using SecScape software v2.7 (Applied Biosystems). A reference gyrA sequence (GenBank accession NC002677) was used to align the sequences.

False-positive amplifications were addressed by using individual sterile section-cutting blades and sterile glassware for each biopsy sample. The armadillo biopsies and extracted DNA samples were carefully identified and kept in separate boxes. A simple DNA extraction protocol was established to minimise the risk of contamination. The extraction method used one purification step to reduce the accumulation of impurities that would inhibit the polymerase reaction.

Ethical considerations - This project was submitted to and approved by the Ethical Committee of the Federal University of Ceará.

\section{RESULTS}

A total of 116 liver, spleen, ear and nose tissue samples from 29 armadillos were tested using the nested RLEP PCR assay. M. leprae was detected in six (21\%) of the animals; five were from the species $D$. novemcinctus (samples 8, 21, 22, 23 and 25) and one was from the species E. sexcinctus (sample 9) (Table I). M. leprae DNA was amplified in the ear biopsy samples of all six animals, but in only five of the liver or nose biopsy samples and three of the spleen biopsy samples (Table II).

The PCR amplification of $M$. leprae with the primers RLEP2-3 and RLEP2-2 was species-specific, targeting the same region of the primers developed by Donoghue et al. (2001). It generated a single band of $238 \mathrm{bp}$, a larger amplicon compared to the Donoghue primers that amplified a 99-bp product. In addition, the sequencing of the gyrA region (coding sequence location from 7515 to $11451 \mathrm{~kb}$ ) was confirmatory for the presence of $M$. leprae DNA in the armadillos analysed. The detection limit of the nested PCR for $M$. leprae was $1 \mathrm{pg} / \mu \mathrm{L}$ (data not shown). All negative samples were amplified after adding $1 \mathrm{pg}$ of purified $M$. leprae DNA. The exception was for one sample that was only amplified after a 1000-fold dilution, therefore confirming the presence of substances that were inhibitory to the PCR. The assay was repeated for the few isolates for which there were discrepancies between the researchers.

\section{DISCUSSION}

This is the first study to identify $M$. leprae in two species of wild armadillos (D. novemcinctus and $E$. sexcinctus) in Brazil. The tested armadillos came from an endemic leprosy area where the prevalence rate was reported to be $2.99 / 100,000$ inhabitants in 2008 and where there is continuous contact between humans and these animals (MS/SVS 2011). In this region, the hunting and eating of armadillos is a popular and frequent practice, a situation similar to that described in Colombia (CardonaCastro et al. 2009). It is noteworthy that previous studies in the Americas and in the USA (Louisiana), Mexico, Colombia and Brazil had only reported $M$. leprae infection in armadillos of the species D. novemcinctus (Meyers et al. 1977, Truman et al. 1990, Deps et al. 2002).

Clinically, most of the animals exhibited nodulelike lesions indicative of leprosy or other degenerative diseases, as demonstrated by a clinical exam conducted by an expert veterinarian. However, no histopathological study was conducted, as the tissue samples were not formalin-fixed for anatomopathological examination. Additionally, no blood samples were taken from the animals. Therefore, we cannot conclude that the PCRpositive armadillos had clinical leprosy.

The genome sequencing of the Tamil Nadu M. leprae strain and other strains was conducted with a typing system based on single-nucleotide polymorphism (SNP) differences allowing continent distribution of the leprosy bacilli, which were classified as SNP types 1 to 4 (Monot et al. 2005). In addition, a correlation was observed between a mutation in the gyrA gene and the SNP types, which were clustered in gyrAC and gyrAT populations; the T SNP represents SNP type 3, while the C nucleotide represents the other three types. The results from the sequencing data demonstrated that the analysed samples from the armadillos in CE belong to the gyrAT (SNP type 3) population, which was also identified in samples from wild armadillos in Louisiana (Monot et al. 2005) and in humans in Brazil (Fontes et al. 2009). Although this is not yet definitive evidence that armadillos act as a source of

\section{TABLE I}

Polymerase chain reaction (PCR) results for the 29 wild armadillos analyzed according to the armadillo species in the state of Ceará, Brazil

\begin{tabular}{lcc}
\hline Armadillo species & $\begin{array}{c}\text { Total } \\
(\mathrm{n})\end{array}$ & $\begin{array}{c}\text { RLEP PCR positive } \\
\mathrm{n}(\%)\end{array}$ \\
\hline $\begin{array}{l}\text { Dasypus novemcinctus } \\
\text { Euphractus sexcintus }\end{array}$ & 27 & $5(19)$ \\
\hline Total & 2 & $1(50)$ \\
\hline
\end{tabular}

RLEP: Mycobacterium leprae-specific repetitive element.

TABLE II

Distribution of positive polymerase chain reaction (PCR) results using the Mycobacterium leprae-specific repetitive element repetitive sequence primer pairs in different biopsy tissues from wild armadillos in the state of Ceará, Brazil

\begin{tabular}{lcccc}
\hline & \multicolumn{5}{c}{ Biopsy source } \\
\cline { 2 - 5 } Armadillo species & Liver & Spleen & Ear & Nose \\
\hline Dasypus novemcinctus $(\mathrm{n}=5)$ & 4 & 2 & 5 & 4 \\
Euphractus sexcinctus $(\mathrm{n}=1)$ & 1 & 1 & 1 & 1 \\
\hline
\end{tabular}


infection for humans, this contributes to the evidence supporting the hypothesis of zoonotic transmission, as suggested by other authors (Job et al. 1986, Walsh et al. 1988, Cardona-Castro et al. 2009, Truman \& Fine 2010).

Because $M$. leprae cannot be cultivated in vitro, its detection is based on the histopathological demonstration of the bacilli in dermal nerves, mouse footpad cultivation and PCR assays of the selective amplification of M. leprae DNA (Truman \& Fine 2010). This study used the RLEP repetitive element sequence of M. leprae, which is reported to be specific for M. leprae and is not present in other mycobacterial or bacterial species. In addition, the use of the repetitive sequence as the PCR target DNA provides the advantage of higher sensitivity over other targets because it is present at multiple sites in the genomic DNA (Donoghue et al. 2001, Truman et al. 2008). It has been suggested that many homologous sequences of the RLEP may be present in other environmental Mycobacterium species that have not been thoroughly investigated, which might generate false-positive results. Despite this fact, Martinez et al. (2011) found that the RLEP PCR assay can be used as a more specific and sensitive diagnostic test to detect $M$. leprae infection compared to the ones based on gene targets $\mathrm{Ag} 85 \mathrm{~B}$, sodA and 16S rRNA. Because we used several strategies to minimise false-positive amplifications and contamination, we are confident that these are real infections.

In conclusion, the presence of $M$. leprae DNA in wild armadillos (D. novemcinctus and $E$. sexcinctus) in a leprosy transmission area in Brazil provides additional evidence supporting the hypothesis that armadillos can play a role as an environmental reservoir for the bacillus in this area. Moreover, the finding supports the idea that intensive contact with these animals may increase the risk of infection in $\mathrm{CE}$. The current global control strategy depends on treating all human cases, but a definitive identification of an animal reservoir, as suggested by Truman et al. (2011), could challenge this strategy and may partially explain the continuing and growing presence of leprosy in the studied area. More detailed molecular studies will be useful in monitoring and confirming the transmission of M. leprae between wild armadillos and humans and in guiding new strategies for prevention.

\section{REFERENCES}

Amezcua ME, Escobar-Gutierrez A, Storrs EE, Dhople AM, Burchfield HP 1984. Wild Mexican armadillo with leprosy-like infection. Int J Lepr Other Mycobact Dis 52: 254-255.

Armadillo Online! 2012. [homepage on the Internet]. Minneapolis. Armadillos: Biology, Ecology and Images. Michigan State University Department of Zoology. [cited 2012 March 13]. Available from: msu.edu/ nixonjos/armadillo/species.html.

Bruce S, Schroeder TL, Ellner K, Rubin H, Williams T, Wolf Jr JE 2000. Armadillo exposure and Hansen's disease: an epidemiologic survey in southern Texas. J Am Acad Dermatol 43: 223-228.

Cardona-Castro N, Beltran-Alzate JC, Romero-Montoya IM, Melendez E, Torres F, Sakamuri RM, Li W, Vissa V 2009. Identification and comparison of Mycobacterium leprae genotypes in two geographical regions of Colombia. Lepr Rev 80: 316-321.

Clark BM, Murray CK, Horvath LL, Deye GA, Rasnake MS, Longfield RN 2008. Case-control study of armadillo contact and Hansen's disease. Am J Trop Med Hyg 78: 962-967.
Dalponte JC, Tavares-Filho JA 2004. Diet of the yellow armadillo, Euphractus sexcinctus, in south-central Brazil. Edentata 6: 37-41.

de Wit MY, Faber WR, Krieg SR, Douglas JT, Lucas SB, Montreewasuwat N, Pattyn SR, Hussain R, Ponnighaus JM, Hartskeerl RA 1991. Application of a polymerase chain reaction for the detection of $M y$ cobacterium leprae in skin tissues. J Clin Microbiol 29: 906-910.

Deps PD, Alves BL, Gripp CG, Aragao RL, Guedes B, Filho JB, Andreatta MK, Marcari RS, Prates I, Rodrigues LC 2008. Contact with armadillos increases the risk of leprosy in Brazil: a case control study. Indian J Dermatol Venereol Leprol 74: 338-342.

Deps PD, Antunes JM, Tomimori-Yamashita J 2007. Detection of Mycobacterium leprae infection in wild nine-banded armadillos (Dasypus novemcinctus) using the rapid ML Flow test. Rev Soc Bras Med Trop 40: 86-87.

Deps PD, Santos AR, Yamashita-Tomimori J 2002. Detection of Mycobacterium leprae DNA by PCR in blood sample from ninebanded armadillo: preliminary results. Int J Lepr Other Mycobact Dis 70: 34-35.

Donoghue HD, Holton J, Spigelman M 2001. PCR primers that can detect low levels of Mycobacterium leprae DNA. J Med Microbiol 50: 177-182.

Fontes AN, Sakamuri RM, Baptista IM, Ura S, Moraes MO, Martinez AN, Sarno EN, Brennan PJ, Vissa VD, Suffys PN 2009. Genetic diversity of Mycobacterium leprae isolates from Brazilian leprosy patients. Lepr Rev 80: 302-315.

Job CK, Drain V, Truman R, Deming AT, Sanchez RM, Hastings RC 1992. The pathogenesis of leprosy in the nine-banded armadillo and the significance of IgM antibodies to PGL-1. Indian J Lepr 64: 137-151.

Job CK, Harris EB, Allen JL, Hastings RC 1986. A random survey of leprosy in wild nine-banded armadillos in Louisiana. Int J Lepr Other Mycobact Dis 54: 453-457.

Kerr-Pontes LR, Barreto ML, Evangelista CM, Rodrigues LC, Heukelbach J, Feldmeier H 2006. Socioeconomic, environmental and behavioural risk factors for leprosy in Northeast Brazil: results of a case-control study. Int J Epidemiol 35: 994-1000.

Kirchheimer WF, Sanchez RM 1977. Quantitative aspects of leprosy in armadillos. Lepr India 49: 48-53.

Kirchheimer WF, Storrs EE, Binford CH 1972. Attempts to establish the Armadillo (Dasypus novemcinctus linn.) as a model for the study of leprosy. II. Histopathologic and bacteriologic post-mortem findings in lepromatoid leprosy in the Armadillo. Int J Lepr Other Mycobact Dis 40: 229-242.

Martinez AN, Ribeiro-Alves M, Sarno EN, Moraes MO 2011. Evaluation of qPCR-based assays for leprosy diagnosis directly in clinical specimens. PLoS Negl Trop Dis 5: e1354.

Meyers WM, Walsh GP, Brown HL, Rees RJ, Convit J 1977. Naturally acquired leprosy-like disease in the nine-banded armadillo (Dasypus novemcinctus): reactions in leprosy patients to lepromins prepared from naturally infected armadillos. $J$ Reticuloendothel Soc 22: 369-375.

Monot M, Honore N, Garnier T, Araoz R, Coppee JY, Lacroix C, Sow S, Spencer JS, Truman RW, Williams DL, Gelber R, Virmond M, Flageul B, Cho SN, Ji B, Paniz-Mondolfi A, Convit J, Young S, Fine PE, Rasolofo V, Brennan PJ, Cole ST 2005. On the origin of leprosy. Science 308: 1040-1042.

MS/SVC - Ministério da Saúde/Secretaria de Vigilância em Saúde 2008. Situação epidemiológica da hanseníase no Brasil. Programa Nacional de Controle de Hanseníase. [cited 2012 March 13]. Available from: portal.saude.gov.br/portal/arquivos/pdf/boletim novembro.pdf. 
MS/SVC - Ministério da Saúde/Secretaria de Vigilância em Saúde 2011. Taxa de prevalencia de hanseníase 2011. [updated 2011 June; cited 2012 March 13]. Available from: tabnet.datasus.gov. br/cgi/idb2010/matriz.htm\#morb.

Penna ML, de Oliveira ML, Penna GO 2009. The epidemiological behaviour of leprosy in Brazil. Lepr Rev 80: 332-344.

Schmitt JV, Dechandt IT, Dopke G, Ribas ML, Cerci FB, Viesi JMZ, Marchioro HZ, Zunino MMB, Miot HA 2010. pArmadillo meat intake was not associated with leprosy in a case control study, Curitiba (Brazil). Mem Inst Oswaldo Cruz 105: 857-862.

Sheppard CC 1960. The experimental disease that follows the injection of human leprosy bacilli into footpads of mice. $J$ Expect Med 112: 445 .

Sheppard CC 1985. Experimental leprosy. In RC Hastings (ed.), Leprosy, Longman Group Limited, New York, p. 269-286.

Smith JH, Long EG, Crouse DT, Christie JD, Folse DS, Imaeda T, Barksdale L 1983. Leprosy in wild armadillos (Dasypus novemcinctus) of the Texas Gulf Coast. Acta Leprol 2: 311-318.

Stallknecht DE, Truman RW, Hugh-Jones ME, Job CK 1987. Surveillance for naturally acquired leprosy in a nine-banded armadillo population. $J$ Wildl Dis 23: 308-310.

Truman R 2008. Armadillos as a source of infection for leprosy. South Med J 101: 581-582.

Truman RW, Andrews PK, Robbins NY, Adams LB, Krahenbuhl JL, Gillis TP 2008. Enumeration of Mycobacterium leprae using real-time PCR. PLoS Negl Trop Dis 2: e328.
Truman RW, Fine PE 2010. "Environmental" sources of Mycobacterium leprae: issues and evidence. Lepr Rev 81: 89-95.

Truman RW, Job CK, Hastings RC 1990. Antibodies to the phenolic glycolipid-1 antigen for epidemiologic investigations of enzootic leprosy in armadillos (Dasypus novemcinctus). Lepr Rev 61: 19-24.

Truman RW, Kumaresan JA, McDonough CM, Job CK, Hastings RC 1991. Seasonal and spatial trends in the detectability of leprosy in wild armadillos. Epidemiol Infect 106: 549-560.

Truman RW, Singh P, Sharma R, Busso P, Rougemont J, Paniz-Mondolfi A, Kapopoulou A, Brisse S, Scollard DM, Gillis TP, Cole ST 2011. Probable zoonotic leprosy in the southern United States. N Engl J Med 364: 1626-1633.

Walsh GP, Meyers W, Binford CH 1977. Naturally acquired leprosylike disease in the nine-banded armadillo (Dasypus novemcinctus): recent epizootiologic findings. J Reticuloendothel Soc 22: 363-367.

Walsh GP, Meyers WM, Binford CH, Gormus BJ, Baskin GB, Wolf RH, Gerone PJ 1988. Leprosy as a zoonosis: an update. Acta Leprol 6: 51-60.

WHO - World Health Organization 2011. Weekly epidemiological record. Available from: who.int/wer/2011/wer8636.pdf.

Zumarraga MJ, Resoagli EH, Cicuta ME, Martinez AR, Oritiz de Rott MI, de Millan SG, Caimi K, Gioffre A, Alito A, Bigi F, Cataldi AA, Romano MI 2001. PCR-restriction fragment length polymorphism analysis (PRA) of Mycobacterium leprae from human lepromas and from a natural case of an armadillo of Corrientes, Argentina. Int J Lepr Other Mycobact Dis 69: 21-25. 